\title{
Effects of cordycepin on HepG2 and EA.hy926 cells: Potential antiproliferative, antimetastatic and anti-angiogenic effects on hepatocellular carcinoma
}

\author{
HAISHENG LU ${ }^{1}$, XITING LI ${ }^{2}$, JIANYING ZHANG ${ }^{2}, \mathrm{HUI} \mathrm{SHI}^{3}$, XIAOFENG ZHU ${ }^{1}$ and XIAOSHUN HE ${ }^{1}$ \\ ${ }^{1}$ Organ Transplantation Center, First Affiliated Hospital, Sun Yat-Sen University, Guangzhou, Guangdong 510080; \\ ${ }^{2}$ Department of Periodontology, Guanghua School of Stomatology, Sun Yat-Sen University, Guangzhou, Guangdong 510055; \\ ${ }^{3}$ Department of Radiology, The Affiliated Hexian Memorial Hospital, Southern Medical University, \\ Guangzhou, Guangdong 511400, P.R. China
}

Received July 1, 2013; Accepted January 15, 2014

DOI: $10.3892 / \mathrm{ol} .2014 .1965$

\begin{abstract}
Hepatocellular carcinoma (HCC) is a hypervascular tumor and accumulating evidence suggests that angiogenesis plays an important role in HCC development. Cordycepin, also known as 3'-deoxyadenosine, is a derivative of adenosine, and numerous cellular enzymes cannot differentiate the two. The aim of the present study was to determine whether cordycepin regulates proliferation, migration and angiogenesis in a human umbilical vein endothelial cell line (EA.hy926) and in a hepatocellular carcinoma cell line (HepG2). MTT was used to assess cell proliferation. Apoptosis was analyzed by flow cytometry (propidium iodide staining). Transwell and wound healing assays were used to analyze the migration and invasion of HepG2 and EA.hy926 cells. Angiogenesis in EA.hy926 cells was assessed using a tube formation assay. Cordycepin strongly suppressed HepG2 and EA.hy926 cell proliferation in a dose- and time-dependent manner. Cordycepin induced EA.hy926 cell apoptosis in a dose-dependent manner $(2,000 \mu \mathrm{g} / \mathrm{ml}: 50.20 \pm 1.55 \%$ vs. $0 \mu \mathrm{g} / \mathrm{ml}: 2.62 \pm 0.19 \%$; $<<0.01)$. Cordycepin inhibited EA.hy926 cell migration (percentage of wound healing area, 2,000 $\mu \mathrm{g} / \mathrm{ml}: 3.45 \pm 0.29 \%$ vs. $0 \mu \mathrm{g} / \mathrm{ml}$ : $85.48 \pm 0.84 \%$; $\mathrm{P}<0.05$ ), as well as tube formation (total length of tubular structure, $1,000 \mu \mathrm{g} / \mathrm{ml}: 107 \pm 39 \mu \mathrm{m}$ vs. $0 \mu \mathrm{g} / \mathrm{ml}$ : $936 \pm 56 \mu \mathrm{m} ; \mathrm{P}<0.05)$. Cordycepin also efficiently inhibited HepG2 cell invasion and migration. High-performance liquid chromatography analysis of the cytosol from EA.hy926 cells showed that cordycepin was stable for $3 \mathrm{~h}$. In conclusion, cordycepin not only inhibited human HepG2 cell proliferation and invasion, but also induced apoptosis and inhibited migration
\end{abstract}

Correspondence to: Dr Xiaofeng Zhu, Organ Transplantation Center, First Affiliated Hospital, Sun Yat-Sen University, 58 Zhongshan Er Road, Guangzhou, Guangdong 510080, P.R. China E-mail: luhaisheng2013@126.com

Key words: cordycepin, angiogenesis, invasion, hepatocellular carcinoma, apoptosis, vascular endothelial cells and angiogenesis in vascular endothelial cells, suggesting that cordycepin may be used as a novel anti-angiogenic therapy in HCC.

\section{Introduction}

Hepatocellular carcinoma (HCC) is responsible for over 600,000 mortalities each year; it is the sixth most common type of cancer in the world and the third greatest cause of cancer mortality (1-3). HCC prognosis is generally poor and the 5-year survival rate is $<7 \%$ (4). Surgical resection and liver transplantation are still recognized as effective curative approaches for HCC; however, they are possible in only a small number of patients. Eventually, the majority of patients exhibit intrahepatic recurrences that quickly progress to an advanced disease, with blood vessel invasion and multiple extrahepatic metastases (5). Angiogenesis is a complex process based on the activation, proliferation and migration of endothelial cells. During angiogenesis, endothelial cells are activated by angiogenic factors. The cells then secrete proteases to dissolve their basement membrane, allowing their migration toward the angiogenic signal, where they can proliferate and form new blood vessels (6). Uncontrolled cell proliferation and angiogenesis play critical roles in HCC growth, pathological classification, metastatic spread and prognosis (7).

Chemotherapy is often the only treatment for advanced and inoperable HCC. However, its outcomes are often discouraging due to poor tolerance and low efficacy (8). In the recent decade, natural products have been a rich source of compounds with numerous applications in cancer therapy, without the associated side effects. For these reasons, a number of researchers are trying to screen antitumor compounds from various natural substances. Cordycepin (3'-deoxyadenosine), is the major bioactive component of Cordyceps militaris (9) and is a natural structural analog of adenosine (10). Its pharmacokinetic profile indicates that the cordycepin-induced metabolite is suppressed by an adenosine deaminase inhibitor in vivo, and that it has a short half-life and high rates of clearance (11). This molecule was shown more than 40 years ago to have antitumor activities in rodent and human in vivo and 
in vitro systems (12-14). However, in previous studies, different sources and various concentrations of purified cordycepin affect the consistency of these conclusions. In vitro, cordycepin was tested in various cancer cells, including breast, prostate, colon, leukemia and lung carcinoma cells (15-20), as well as in hepatic cancer cells (21-24).

A number of previous studies have assessed the effects of cordycepin on HCC cells; however, the effects of cordycepin on vascular endothelial cell migration and angiogenesis require investigation. Furthermore, no information is available regarding the intracellular levels of cordycepin following treatment in endothelial cells. Therefore, the primary aim of the present study was to assess the antimigration and anti-angiogenic effects of cordycepin on vascular endothelial cells, and the stability of intracellular cordycepin levels following administration.

\section{Materials and methods}

Reagents. Professor Li from the South China Normal University (Guangzhou, China) developed a novel column chromatography extraction method for the extraction of cordycepin from solid rice-based fermentation medium. Using this method, cordycepin is obtained at a $98 \%$ purity, with an overall recovery rate of $90 \%$ (25). Cordycepin was provided by his laboratory and was freshly prepared as stock solution in double-distilled water. It was diluted in culture medium at concentrations of $125,250,500,1,000$ and 2,000 $\mu \mathrm{g} / \mathrm{ml}$ prior to experiments. Dulbecco's modified Eagle's medium (DMEM) and 4', 6-Diamidino-2-phenylindole (DAPI) were purchased from Invitrogen Corporation (Carlsbad, CA, USA). Fetal bovine serum (FBS) was purchased from Gibco Industries Inc. (Big Cabin, OK, USA) and the cell apoptosis propidium iodide (PI) detection kit was purchased from Nanjing KeyGen Biotechnology Co., Ltd. (Nanjing, China). 3-(4,5-Dimethylthiazol-2-yl)-2,5-diphenyltetrazoliumbromide (MTT) and dimethyl sulfoxide (DMSO) were purchased from Sigma-Aldrich (St. Louis, MO, USA). MTT was dissolved in phosphate-buffered saline (PBS; Gibco, Carlsbad, CA, USA) and stored in the dark. Transwell chamber and Matrigel were purchased from BD Biosciences (San Jose, CA, USA). All reagents were of analytical grade, unless otherwise specified.

Cell culture. Human HCC cells (HepG2) and human endothelial-like immortalized cells (EA.hy926) were obtained from the Cell Bank of Type Culture Collection of Chinese Academy of Sciences (Shanghai, China). EA.hy926 and HepG2 cells were cultured in DMEM supplemented with $10 \%(\mathrm{v} / \mathrm{v})$ heat-inactivated fetal calf serum, penicillin $(100 \mathrm{U} / \mathrm{ml})$ and streptomycin $(100 \mathrm{U} / \mathrm{ml})$ (both Sigma-Aldrich). Cultures were maintained at $37^{\circ} \mathrm{C}$ in a humidified atmosphere containing $5 \%$ $\mathrm{CO}_{2}$ and $95 \%$ air. The medium was changed every two days.

Cell viability assay. Cell survival changes in response to cordycepin were evaluated by MTT assay $(8,26)$. Briefly, $2 \times 10^{4}$ cells in $100 \mu \mathrm{l}$ DMEM supplemented with $2 \%(\mathrm{v} / \mathrm{v})$ heat-inactivated FBS, penicillin $(100 \mathrm{U} / \mathrm{ml})$ and streptomycin (100 U/ml) were seeded into 96-well plates. Medium without cells was used as a blank control. Confluent cells were treated with various concentrations of cordycepin $(125,250,500$,
1,000 and 2,000 $\mu \mathrm{g} / \mathrm{ml}$ ) for 1, 2, 3, 4 and 5 days. The same volume of double-distilled water was used as the negative control $(0 \mu \mathrm{g} / \mathrm{ml})$. At the designed time points, $100 \mathrm{ml} \mathrm{MTT}$ solution in PBS was added to obtain a final concentration of $0.5 \mathrm{~g} / \mathrm{ml}$, and the incubation was continued at $37^{\circ} \mathrm{C}$ for $4 \mathrm{~h}$. Finally, the medium was removed and replaced with $200 \mu \mathrm{l}$ DMSO. The mixture was quantified by determining its absorbance at $540 \mathrm{~nm}$ using a SpectraFluor Plus Reader (Tecan AG, Hombrechtikon, Switzerland). The relative growth rate was calculated as optical density (OD) $)_{\text {test group }} / \mathrm{OD}_{\text {negative control }}$.

Flow cytometric detection of apoptotic cells. Assessment of apoptotic cells was performed according to published methods $(27,28)$. EA.hy926 cells were exposed to various concentrations of cordycepin $(0,250,500,1,000$ and 2,000 $\mu \mathrm{g} / \mathrm{ml})$. They were treated with trypsin-EDTA (Sigma-Aldrich) and collected by centrifugation at $150 \mathrm{x}$ g for $10 \mathrm{~min}$, then thoroughly rinsed with PBS. Pellets were resuspended in ice-cold $70 \%$ ethanol and fixed at $-20^{\circ} \mathrm{C}$ for $24 \mathrm{~h}$. Cells were then centrifuged (1,000 rpm for $15 \mathrm{~min}$ ) and ethanol was removed by washing thoroughly with PBS. Cell pellets were resuspended in $1 \mathrm{ml}$ DNA-staining reagent containing $50 \mu \mathrm{g} / \mathrm{ml}$ RNase, $0.1 \%$ Triton $\mathrm{X}-100,0.1 \mathrm{mmol}$ EDTA (pH 7.4) and $50 \mu \mathrm{g} / \mathrm{ml}$ PI which was provided with the cell apoptosis PI detection kit. Samples were stored in the dark at $4^{\circ} \mathrm{C}$ for $30 \mathrm{~min}$. Red fluorescence (DNA) was detected through a 563-607 nm band-pass filter using a FC 500 MCL/MPL flow cytometer (Beckman Coulter, Brea, CA, USA). In flow cytometry histograms, apoptotic cells have a signal in the sub-diploid regions, which are well-separated from the normal G1 peak. A total of $10^{5}$ cells in each sample were analyzed and the percentage of apoptotic cell accumulation in the sub-G1 peak was calculated.

Transwell migration and invasion assays. A Transwell chamber containing an $8-\mu \mathrm{m}$ pore polycarbonate membrane filter was coated either with Matrigel (for invasion) or without Matrigel (for migration) and inserted in a 24-well culture plate. HepG2 cells were pre-treated with 0, 125, 250, 500 and $1,000 \mu \mathrm{g} / \mathrm{ml}$ cordycepin for $24 \mathrm{~h}$. The cells were then detached with trypsin-EDTA and resuspended in serum-free DMEM. After filling the lower chamber with media supplemented with $10 \%$ FBS as a chemoattractant, $10^{5}$ cells/well in $0.2 \mathrm{ml}$ serum-free DMEM were loaded in the upper chambers. The apparatus was incubated at $37^{\circ} \mathrm{C}$ in a humidified chamber with $5 \% \mathrm{CO}_{2}$ for $12 \mathrm{~h}$ (migration assay) or $24 \mathrm{~h}$ (invasion assay). Following incubation, the filter was removed. Cells in the upper chamber that did not migrate were scraped away with a cotton swab. The transmembrane cells were fixed in methanol for $30 \mathrm{~min}$, washed twice with PBS and stained with $300 \mathrm{nM}$ DAPI for $5 \mathrm{~min}$. Migrating or invading cells were photographed using an inverted microscope (Axio Observer Z1; Carl Zeiss AG, Oberkochen, Germany) and were counted in five randomly selected fields per membrane, then the averages were calculated. Presented data are representative of three individual wells.

Wound healing assay. EA.hy926 cells were cultured as confluent monolayers, synchronized in 1\% FBS for $24 \mathrm{~h}$ and wounded by removing a 300 - to $500 \mu \mathrm{m}$-wide strip of cells across the well with a standard $200 \mu$ l pipette tip. 
A

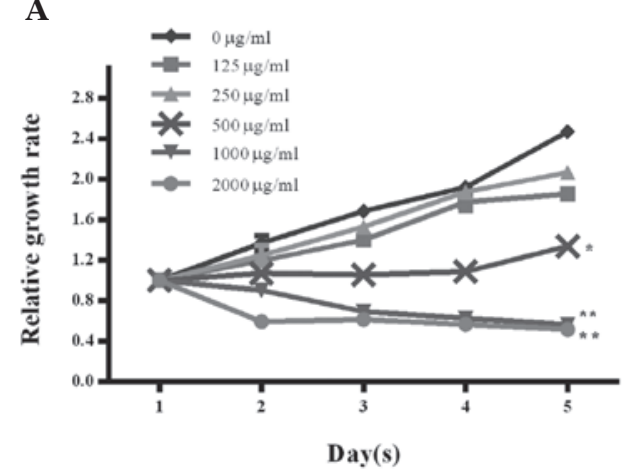

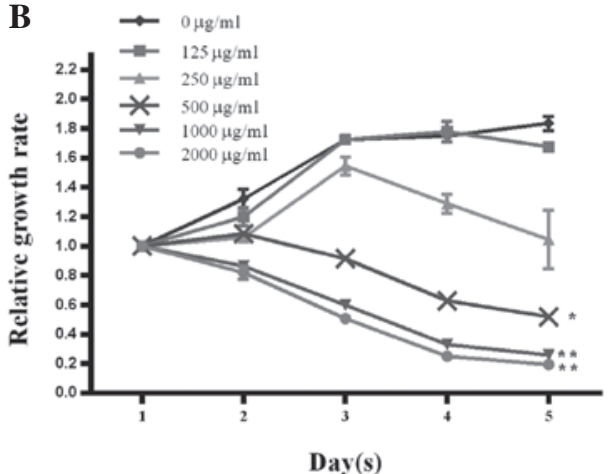

Figure 1. Effects of cordycepin on HepG2 and EA.hy926 cell viability. 3-(4,5-Dimethylthiazol-2-yl)-2,5-diphenyltetrazoliumbromide assay was performed to measure cell viability (the relative growth rate) in (A) EA.hy926 cells and (B) HepG2 cells following treatment with cordycepin at concentrations from 125 to $2,000 \mu \mathrm{g} / \mathrm{ml}$ for $1,2,3,4$ and 5 days. EA.hy926 and HepG2 cells treated without cordycepin $(0 \mu \mathrm{g} / \mathrm{ml})$ were used as the negative control. The data are presented as the mean \pm standard deviation of three independent experiments. ${ }^{*} \mathrm{P}<0.05$ and ${ }^{* *} \mathrm{P}<0.01$, vs. the negative control.

Wounded monolayers were washed twice with PBS to remove non-adherent cells and then treated with 0, 125, 500 and $2,000 \mu \mathrm{g} / \mathrm{ml}$ cordycepin for $6 \mathrm{~h}$. EA.hy926 cell migration was recorded under inverted microscope (Axio Observer Z1; Carl Zeiss AG). Wound healing was quantified, using Image $\mathbf{J}$ software (National Institutes of Health, Bethesda, MD, USA), as follows: Wound healing area $(\%)=$ [cell-free area $(0 \mathrm{~h})$ cell-free area $(6$ h)] / cell-free area $(0$ h) x100 (29).

Tube formation assay for angiogenesis. To investigate the effect of cordycepin on angiogenic activity of EA.hy926 cells in vitro, a tube formation assay was performed following the procedure by Oikawa et al (30). Twenty-four-well cluster tissue culture dishes were coated with $500 \mu \mathrm{g} / \mathrm{ml}$ Matrigel and incubated for $30 \mathrm{~min}$ at $37^{\circ} \mathrm{C}$. EA.hy 926 cells were pre-treated with $0,125,250,500$ and $1,000 \mu \mathrm{g} / \mathrm{ml}$ cordycepin for $12 \mathrm{~h}$ and were then seeded onto solidified gels at a density of $10^{5}$ cells/well in $1 \mathrm{ml}$ culture medium. After $24 \mathrm{~h}$ of incubation, the total lengths of tube-like structures in five randomly selected microscopic fields per well were determined by phase-contrast microscopy and quantified using Image $\mathbf{J}$ software.

High-performance liquid chromatography (HPLC) assay of intracellular cordycepin levels. Intracellular cordycepin levels were measured according to a previously published method (31). EA.hy926 cells were seeded into six-well plates at a density of $1.5-2 \times 10^{6}$ cells/well. After reaching confluence, cells were pretreated with $125 \mu \mathrm{g} / \mathrm{ml}$ cordycepin for $0.5-3 \mathrm{~h}$. In order to investigate intracellular cordycepin levels, the culture medium was removed, the cells were rinsed three times with PBS and were submitted to two freeze-and-thaw cycles, then homogenized on ice. The cell homogenate was centrifuged at $12,000 \mathrm{x} g$ for $15 \mathrm{~min}$ at $4^{\circ} \mathrm{C}$. The supernatant was stored on ice and was filtered through a $0.22-\mu \mathrm{m}$ filter. The supernatant was finally assayed by HPLC (Dalian Elite Analytical Instruments Co., Ltd., Dalian, China) with dual P230 pumps, an UV230+ detector and analytical software. Samples were processed on an YMC-packed C18 column (5 $\mu \mathrm{m}, 250 \times 4.6 \mathrm{~mm})$. The mobile phase consisted of methanol:water $(20: 80 \mathrm{v} / \mathrm{v})$, with a flow rate of $1.0 \mathrm{ml} / \mathrm{min}$. The UV detector was set at $260 \mathrm{~nm}$ and the amount of injected sample was $10 \mu \mathrm{l}$. Quantitative analysis of cordycepin was determined by its peak area based on a standard curve built using $100 \mu \mathrm{g}$ cordycepin. Cordycepin peaks in the samples were identified by the retention time and co-injection tests with the corresponding standard compound. The peak for cordycepin was shown at a retention time of $8.96 \mathrm{~min}$.

Statistical analysis. All investigations were conducted with at least three independent experiments, each performed in triplicates. Data are expressed as the mean \pm standard deviation and were evaluated for statistical significance using one-way analysis of variance followed by Duncan's multiple range tests. GraphPad Prism 5.0 (GraphPad Software Inc., San Diego, CA, USA) was used to perform statistical analysis. $\mathrm{P}<0.05$ was considered to indicate a statistically significant difference.

\section{Results}

Cordycepin inhibits EA.hy926 and HepG2 cell proliferation. To investigate whether cordycepin affects cell proliferation in HCC cells, we performed MTT assays in EA.hy926 and HepG2 cells. As shown in Fig. 1A and B, the relative growth rates were markedly decreased in the presence of high doses of cordycepin exceeding $500 \mu \mathrm{g} / \mathrm{ml}$, indicating that cordycepin inhibited EA.hy926 and HepG2 cell proliferation in a doseand time-dependent manner.

Cordycepin induces EA.hy926 cell apoptosis. To assess whether cordycepin affects apoptosis of endothelial cells, we incubated EA.hy926 cells with 0, 250, 500, 1,000 and $2,000 \mu \mathrm{g} / \mathrm{ml}$ cordycepin for $24 \mathrm{~h}$ and performed a flow cytometry assay. As shown in Fig. $2 \mathrm{~A}$ and B, $250 \mu \mathrm{g} / \mathrm{ml}$ cordycepin had no detectable effect on cell apoptosis, while 500, 1,000 and particularly $2,000 \mu \mathrm{g} / \mathrm{ml}$ cordycepin caused a marked increase in the percentage of apoptotic cells, compared with the negative control $(0 \mu \mathrm{g} / \mathrm{ml})($ all $\mathrm{P}<0.05)$.

Corcydepin inhibits HepG2 cell migration and invasion. In HCC development and metastatic spread, cell migration and invasion are essential processes. To detect antitumor activities of cordycepin on HepG2 cells, Transwell migration and invasion assays either without or with precoated Matrigel were performed following treatment with cordycepin at doses 
A

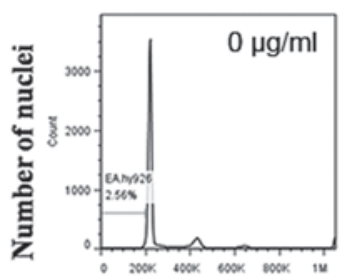

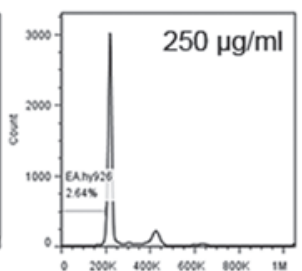
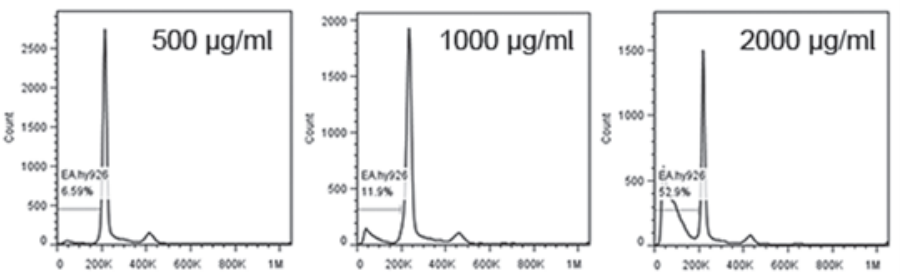

DNA content(PI fluresence)

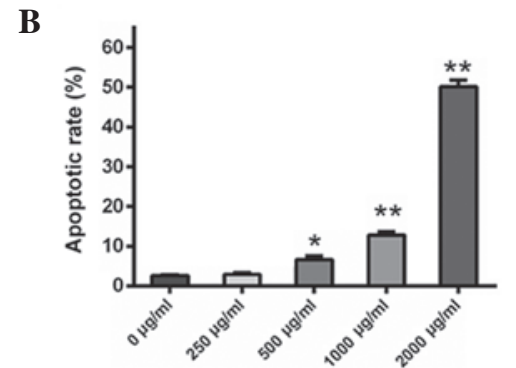

Figure 2. Cordycepin induced apoptosis in EA.hy926 cells. Apoptosis was determined by flow cytometric assay [propidium iodide (PI) staining] (A) Representative flow cytometric plots. EA.hy926 cells were treated with various concentrations of cordycepin $(0,250,500,1,000 \mathrm{and} 2,000 \mu \mathrm{g} / \mathrm{ml})$ for $24 \mathrm{~h}$ (B) The number of apoptotic cells divided by the total number of cells (counted manually), expressed as the percentage of total cells. The data are presented as the mean \pm standard deviation of three independent experiments. ${ }^{*} \mathrm{P}<0.05$ and ${ }^{* *} \mathrm{P}<0.01$, vs. the negative control $(0 \mu \mathrm{g} / \mathrm{ml})$.

A
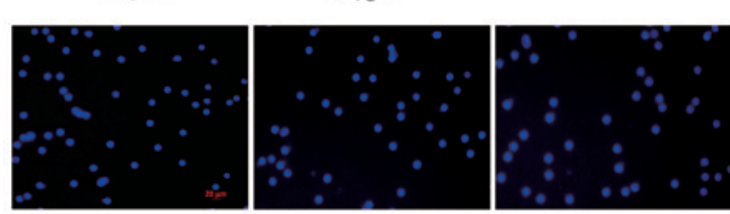

$250 \mu \mathrm{g} / \mathrm{ml}$
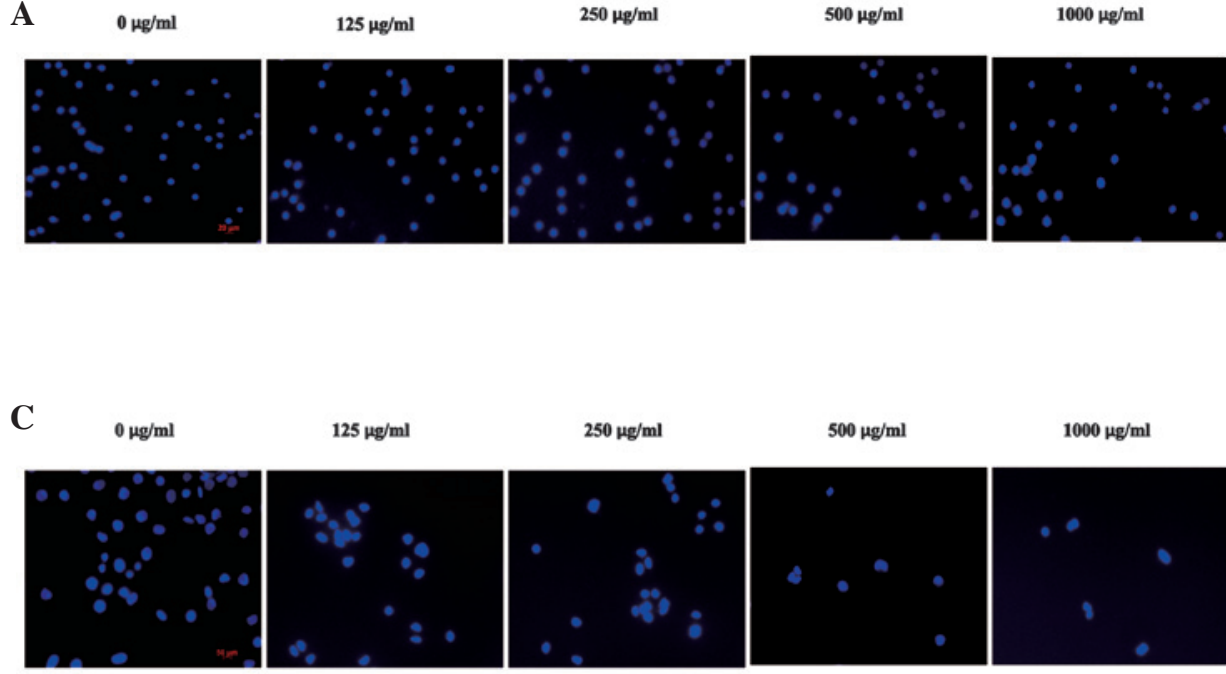

$125 \mu \mathrm{g} / \mathrm{ml}$

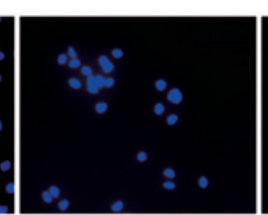

$250 \mu \mathrm{g} / \mathrm{ml}$

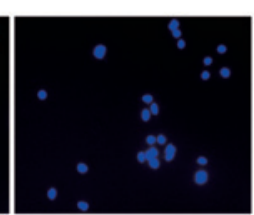

$500 \mu \mathrm{g} / \mathrm{ml}$

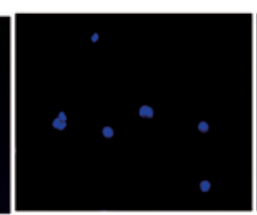

$1000 \mu \mathrm{g} / \mathrm{ml}$

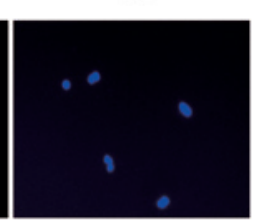

B
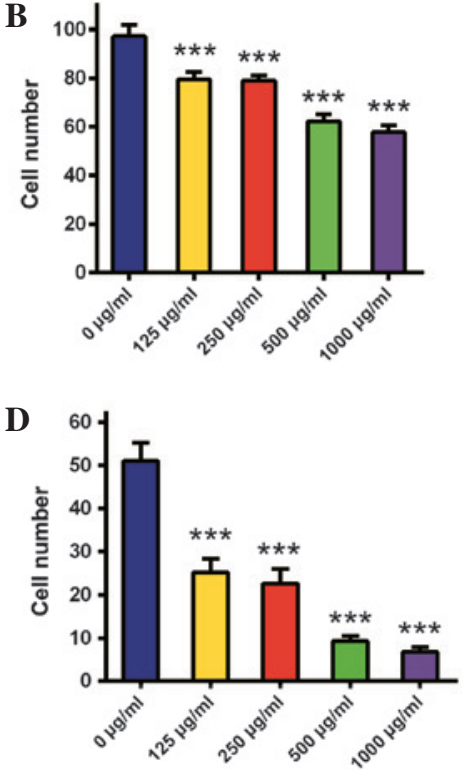

Figure 3. Effects of cordycepin on migration and invasion of HepG2 cells. The migrating and invading abilities of HepG2 cells were examined by Transwell chamber assay. HepG2 cells were treated with various concentrations of cordycepin $(0,125,250,500$ and $1,000 \mu \mathrm{g} / \mathrm{ml}) \mathrm{for} 12 \mathrm{~h}$ (migration assay) or $24 \mathrm{~h}$ (invasion assay). (A and C) Migrating or invading cells were photographed under an inverted fluorescence microscope (A, x100; C, x200). Blue represents DAPI staining. (B and D) Quantification of the numbers of migrating or invading cells are presented as the mean \pm standard deviation of three independent experiments performed in triplicate. ${ }^{*} \mathrm{P}<0.05$ and ${ }^{* *} \mathrm{P}<0.01$, vs. the negative control $(0 \mu \mathrm{g} / \mathrm{ml})$.

of $0,125,250,500$ and $1,000 \mu \mathrm{g} / \mathrm{ml}$. HepG2 migration was significantly suppressed by cordycepin in a dose-dependent manner (all $\mathrm{P}<0.05$; Fig. $3 \mathrm{~A}$ and $\mathrm{B}$ ). The numbers of migrating cells following treatment with cordycepin at doses of 0,125 , 250,500 and $1,000 \mu \mathrm{g} / \mathrm{ml}$ were $97 \pm 5,80 \pm 3,79 \pm 2,62 \pm 3$ and $58 \pm 3$, respectively.

Similarly, HepG2 cell invasion was markedly inhibited in a dose-dependent manner (all $\mathrm{P}<0.05$; Fig. $3 \mathrm{C}$ and $\mathrm{D}$ ). The numbers of invading cells following incubation with 0,125 , 250,500 and $1,000 \mu \mathrm{g} / \mathrm{ml}$ cordycepin were $51 \pm 4,25 \pm 3,23 \pm 3$, $9 \pm 1$ and $7 \pm 1$, respectively. These results demonstrate that cordycepin significantly reduced the potential of HepG2 cells to migrate and invade.

Cordycepin inhibits EA.hy926 cell migrationand angiogenesis. To explore whether cordycepin affects the angiogenic potential of HCC cells, we examined cell migration and angiogenesis by wound healing and tube formation assays in EA.hy926 cells. The wound healing assay demonstrated that the migration of EA.hy926 cells incubated with cordycepin was significantly decreased compared with the negative control $(0 \mu \mathrm{g} / \mathrm{ml})$ (all $\mathrm{P}<0.05)$. After treatment with various concentrations of 
A
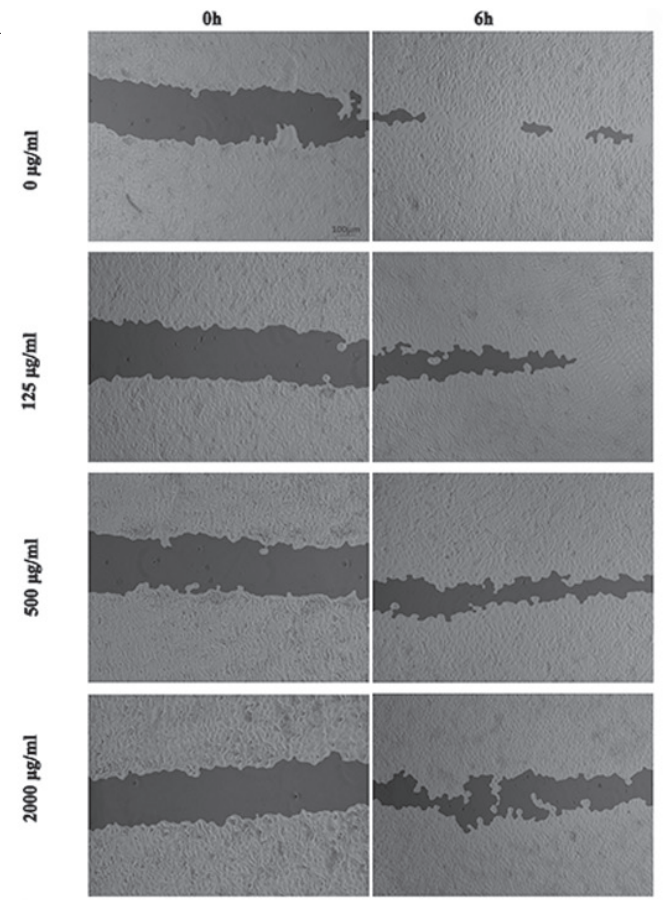

B

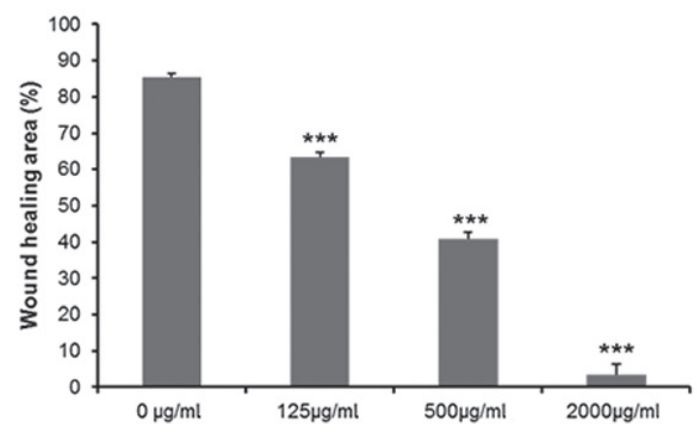

Figure 4. Effect of cordycepin on the migration of EA.hy 926 cells by wound healing assay. EA.hy926 cells were treated with various concentrations of cordycepin $(0,125,500$ and 2,000 $\mu \mathrm{g} / \mathrm{ml})$ for $6 \mathrm{~h}$. (A) Migration of EA.hy 926 cells were photographed under a light microscope (scale bar, $100 \mu \mathrm{m}$ ) and the data were digitally recorded. (B) The percentages of wound healing area are presented as the means \pm standard deviation of three independent experiments. ${ }^{* * * *} \mathrm{P}<0.001$, vs. the negative control $(0 \mu \mathrm{g} / \mathrm{ml})$.

cordycepin for $24 \mathrm{~h}$, the percentage of wound healing area was $85.48 \pm 0.84 \%$ in the negative control cells, $63.50 \pm 1.08 \%$ in $125 \mu \mathrm{g} / \mathrm{ml}$-treated cells, $40.81 \pm 1.76$ in $500 \mu \mathrm{g} / \mathrm{ml}$-treated cells and $3.45 \pm 0.29 \%$ in $2,000 \mu \mathrm{g} / \mathrm{ml}$-treated cells (Fig. 4A and B).

As shown in Fig. 5A, EA.hy926 cells in the negative control aligned to form tube-like structures and crossing tubes with multicentric junctions. EA.hy926 cells treated with various concentrations of cordycepin tended to form fewer tubes, as well as fewer and weaker junctions. The total lengths of tubular structure after incubation with $0,125,250,500$ and $1,000 \mu \mathrm{g} / \mathrm{ml}$ cordycepin for $24 \mathrm{~h}$ were $936 \pm 56,536 \pm 126$, $395 \pm 31,292 \pm 88$ and $107 \pm 39 \mu \mathrm{m}$ (Fig. 5B). The results revealed that cordycepin significantly inhibited migration and angiogenesis of endothelial cells.

Intracellular cordycepin level was stable in EA.hy926 cells. Based on the standard curve of cordycepin, the stability of intracellular cordycepin is shown in Fig. 6A. EA.hy926 cells were incubated with the culture medium (DMEM plus
A $\quad 0 \mu \mathrm{g} / \mathrm{ml}$

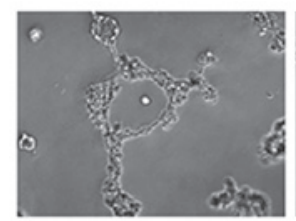

$500 \mu \mathrm{g} / \mathrm{ml}$

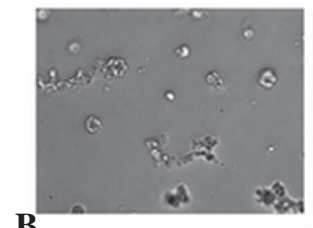

B

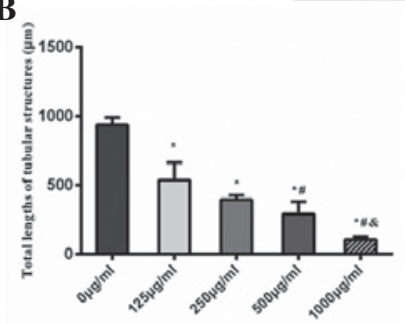

Figure 5. Cordycepin inhibited tube formation of EA.hy926 cells. EA.hy926 cells were treated with different concentrations of cordycepin $(0,125,250$, 500 and $1,000 \mathrm{~g} / \mathrm{ml}$ ) and added to 24-well plates precoated with Matrigel for 24 h. (A) Tube formation of EA.hy926 cells were photographed under a light microscope (magnification, x100). (B) Quantification of the total length of tubular structure under different cordycepin concentrations. ${ }^{*} \mathrm{P}<0.05$, vs. the negative control $(0 \mu \mathrm{g} / \mathrm{ml}) ;{ }^{\prime} \mathrm{P}<0.05$, vs. cells treated with $125 \mu \mathrm{g} / \mathrm{ml}$ cordycepin; ${ }^{\circledR} \mathrm{P}<0.05$, vs. cells treated with $250 \mu \mathrm{g} / \mathrm{ml}$ cordycepin.

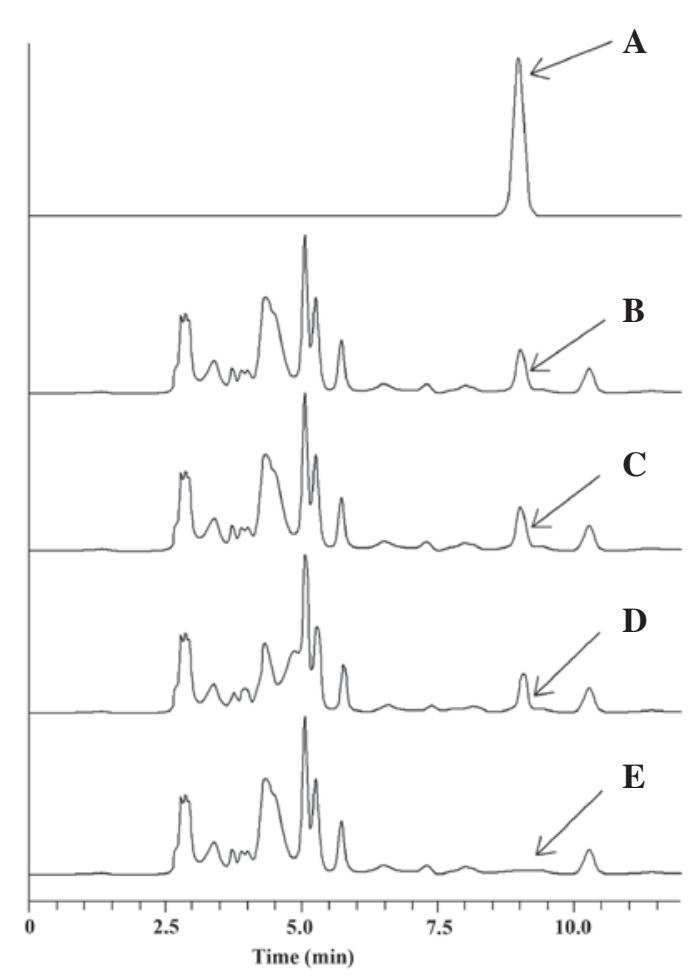

Figure 6. Intracellular cordycepin concentrations in EA.hy926 endothelial cells quantified by high-performance liquid chromatography. Under the chromatographic conditions used, cordycepin had a retention time of $8.96 \mathrm{~min}$. (A) Cordycepin standard curve $(100 \mu \mathrm{g} / \mathrm{ml})$. (B) Intracellular concentration of cordycepin after $0.5 \mathrm{~h}$. (C) Intracellular concentration of cordycepin after $1 \mathrm{~h}$. (D) Intracellular concentration of cordycepin after 3 h. (E) Cytosol of EA.hy926 cells without cordycepin. Arrows show the locations of cordycepin in chromatographic graphs. 
$10 \%$ FBS) containing $125 \mu \mathrm{g} / \mathrm{ml}$ cordycepin from 0.5 to $3 \mathrm{~h}$ (Fig. 6B-D). The cytosol of EA.hy926 cells without cordycepin is shown in Fig. 6E. The cellular content was assayed by HPLC. Under the chromatographic conditions used, cordycepin had a retention time of $8.96 \mathrm{~min}$. The results demonstrated that cordycepin was able to permeate the cell membrane of EA.hy926 cells and was stable during the $3 \mathrm{~h}$ of incubation.

\section{Discussion}

The present study demonstrated that cordycepin extracted from $C$. militaris inhibited HepG2 cell proliferation, migration and invasion. Simultaneously, cordycepin also inhibited vascular endothelial EA.hy926 cell proliferation, migration and angiogenesis, and induced apoptosis. Therefore, cordycepin targeting tumor and endothelial cells may promote the efficacy of therapy in HCC.

C. militaris, from which cordycepin is extracted, has long been used in traditional Chinese medicine (9). Cordycepin exerts numerous pharmacological actions, such as suppression of cell proliferation, activation of apoptosis, and inhibition of cell migration and invasiveness in different tumor cell lines (15,32-35). Cordycepin reduced metastatic nodule formation in mice (34) and has therefore been proposed as an antimetastatic agent. The effects of cordycepin are mainly due to the inhibition of polyadenylation and the activation of AMP-activated protein kinase in the mTOR signaling pathway, in doses over $200 \mu \mathrm{M}(24,36)$. However, only a few reports have focused on the effects of cordycepin on cell proliferation, migration and invasion in HCC cells. The ability of HCC cells to endlessly proliferate is mainly associated with the deregulation of the cell cycle and promotion of invasion. Previous studies suggested that cordycepin reduces lipid deposition and cholesterol levels in HepG2 cells, but has no effect on cell proliferation, and suggested that cordycepin may have a protective effect on the liver $(37,38)$. In an additional study, pure cordycepin at concentrations of $100 \mu \mathrm{M}$ had no inhibitory effects on HepG2 cells and no potent in vitro cytotoxicity (39). However, studies performed in other HCC cell lines, such as BEL-7402 (21), Hep3B (22) and rat $\mathrm{H} 4$ (23) showed results similar to those observed in the present study. Our results also indicated that cordycepin exerts an anti-invasive cytotoxic action in HepG2 cells, and that this effect may contribute, at least in part, to the antimetastatic effect observed in previous studies.

A number of studies have indicated that blood vessel proliferation in a tumor is a hallmark of tumor growth and metastatic spread $(40,41)$. HCC tumor vasculature shows irregular diameter and an abnormal vascular branching pattern; these tumor vessels also typically lack a complete basal membrane and are incompletely covered by pericytes and are therefore leaky (7). Cancer cells can spontaneously fuse with endothelial cells to form hybrid cells, facilitating the invasion of the endothelial barrier to form metastases (42). Since HCC is a hypervascular tumor, uncontrolled angiogenesis plays an important role in HCC development, and thereby anti-angiogenic agents became one of the most promising therapeutic strategies in HCC (43). In our study, we explored the effect of cordycepin on angiogenesis of immortalized human umbilical vein endothelial cells (EA. hy926). These cells are the product of the fusion between human umbilical vein cells and a thioguanine-resistant A549 clone. These cells show morphological, phenotypic and functional characteristics of human endothelial cells, without the limited lifespan and the inter-donors variability. These cells are considered good models for cancer drug screening $(44,45)$. As expected, the results of the present study demonstrated that cordycepin effectively inhibits vascular endothelial cell growth and induces apoptosis. Moreover, it was observed that the anticancer effects of cordycepin are likely to be associated with inhibition of endothelial cell migration and tube formation. Therefore, our results suggested that cordycepin has potential antiangiogenic activity. The effects observed at low doses may be due to decreased polyadenylation of mRNAs, while the effects observed at high doses may be due to the activation of the mTOR pathway $(24,36)$.

A previous study demonstrated that cordycepin exerts its effects at doses over $200 \mu \mathrm{M}$ (24). Additionally, pharmacokinetic data demonstrated that cordycepin has a short half-life and is metabolized in a short period of time. As an adenosine analog, the metabolic pathway for cordycepin may be similar to adenosine. Cordycepin is rapidly deaminated by adenosine deaminase, and is promptly metabolized to an inactive metabolite, 3'-deoxy-hypoxanthinosine $(46,47)$. The half-life of cordycepin in rat blood is $1.6 \pm 0.0 \mathrm{~min}$ after administration, and the measurable concentration of cordycepin in rat blood vanishes within $30 \mathrm{~min}$. Cordycepin-induced compounds appear in the blood and liver for over $2 \mathrm{~h}$ after administration (11). To overcome the problem of rapid elimination, a high dosage must be administered; otherwise, intracellular concentrations would be sub-therapeutic. Hence, the present study used cordycepin at doses ranging from 125 to $2,000 \mu \mathrm{g} / \mathrm{ml}$, which allowed detection and therapeutic effects. Using a HPLC method, we showed that cordycepin is able to permeate the EA.hy 926 cell membrane within $0.5 \mathrm{~h}$ and was stable for the whole studied period $(3 \mathrm{~h})$. Thus, local administration of high doses of cordycepin may be sufficiently potent and specific to destroy enough tumor vasculature to starve the entire tumor.

In conclusion, our results indicate that cordycepin possesses anticancer properties, which are not solely a result of direct cytotoxicity in a HCC cellular model, but also of inhibition of angiogenesis in vascular endothelial cells. Our results also suggest that a dose greater than $500 \mu \mathrm{g} / \mathrm{ml}$ is required in order to observe therapeutic effects. Cordycepin may be a potential anti-angiogenic candidate for cancer therapy in HCC; however, its mechanisms and adverse effects require further investigation.

\section{Acknowledgements}

The authors would like to thank Professor Li (South China Normal University, Guangzhou, China) for generously providing cordycepin. This study was supported by grants from the specialized research fund for the doctoral program of higher education in China (no. 20120171110073) and the Science and Technology Planning Project of Guangdong Province (2010B031600222). 


\section{References}

1. McGlynn KA and London WT: Epidemiology and natura history of hepatocellular carcinoma. Best Pract Res Clin Gastroenterol 19: 3-23, 2005

2. Parkin DM, Bray F, Ferlay J and Pisani P: Global cancer statistics, 2002. CA Cancer J Clin 55: 74-108, 2005.

3. Llovet JM, Burroughs A and Bruix J: Hepatocellular carcinoma Lancet 362: 1907-1917, 2003

4. Azam F and Koulaouzidis A: Hepatitis B virus and hepatocarcinogenesis. Ann Hepatol 7: 125-129, 2008

5. Bosch FX, Ribes J, Diaz M and Cleries R: Primary liver cancer: worldwide incidence and trends. Gastroenterology 127 (5 Suppl 1): S5-S16, 2004.

6. Flamme I, Frolich T and Risau W: Molecular mechanisms of vasculogenesis and embryonic angiogenesis. J Cell Physiol 173: 206-210, 1997.

7. Forner A, Llovet JM and Bruix J: Hepatocellular carcinoma. Lancet 379: 1245-1255, 2012

8. Lopez PM, Villanueva A and Llovet JM: Systematic review: evidence-based management of hepatocellular carcinoma - an updated analysis of randomized controlled trials. Aliment Pharmacol Ther 23: 1535-1547, 2006.

9. Cunningham KG, Manson W, Spring FS and Hutchinson SA: Cordycepin, a metabolic product isolated from cultures of Cordyceps militaris (Linn.) Link. Nature 166: 949, 1950.

10. Lennon MB and Suhadolnik RJ: Biosynthesis of 3'-deoxyadenosine by Cordyceps militaris. Mechanism of reduction. Biochim Biophys Acta 425: 532-536, 1976.

11. Tsai YJ, Lin LC and Tsai TH: Pharmacokinetics of adenosine and cordycepin, a bioactive constituent of Cordyceps sinensis in rat. J Agric Food Chem 58: 4638-4643, 2010.

12. Sugar AM and McCaffrey RP: Antifungal activity of 3'-deoxyadenosine (cordycepin). Antimicrob Agents Chemother 42 : 1424-1427, 1998

13. Jagger DV, Kredich NM and Guarino AJ: Inhibition of Ehrlich mouse ascites tumor growth by cordycepin. Cancer Res 21: 216-220, 1961

14. Rich MA, Meyers P, Weinbaum G, Cory JG and Suhadolnik RJ Inhibition of human tumor cells by cordycepin. Biochim Biophys Acta 95: 194-204, 1965.

15. Nakamura K, Yoshikawa N, Yamaguchi Y, et al: Antitumor effect of cordycepin (3'-deoxyadenosine) on mouse melanoma and lung carcinoma cells involves adenosine A3 receptor stimulation. Anticancer Res 26: 43-47, 2006.

16. Wehbe-Janek H,ShiQ and Kearney CM: Cordycepin/hydroxyurea synergy allows low dosage efficacy of cordycepin in MOLT-4 leukemia cells. Anticancer Res 27: 3143-3146, 2007.

17. Lee SJ, Kim SK, Choi WS, Kim WJ and Moon SK: Cordycepin causes p21WAF1-mediated G2/M cell-cycle arrest by regulating c-Jun N-terminal kinase activation in human bladder cancer cells. Arch Biochem Biophys 490: 103-109, 2009.

18. Choi S, Lim MH, Kim KM, Jeon BH, Song WO and Kim TW: Cordycepin-induced apoptosis and autophagy in breast cancer cells are independent of the estrogen receptor. Toxicol Appl Pharmacol 257: 165-173, 2011

19. Lee SJ, Moon GS, Jung KH, Kim WJ and Moon SK: c-Jun $\mathrm{N}$-terminal kinase 1 is required for cordycepin-mediated induction of G2/M cell-cycle arrest via p21WAF1 expression in human colon cancer cells. Food Chem Toxicol 48: 277-283, 2010

20. Jeong JW, Jin CY, Park C, et al: Inhibition of migration and invasion of $\mathrm{LNCaP}$ human prostate carcinoma cells by cordycepin through inactivation of Akt. Int J Oncol 40: 1697-1704, 2012.

21. Shi P, Huang Z, Tan X and Chen G: Proteomic detection of changes in protein expression induced by cordycepin in human hepatocellular carcinoma BEL-7402 cells. Methods Find Exp Clin Pharmacol 30: 347-353, 2008.

22. Wang BJ, Won SJ, Yu ZR and Su CL: Free radical scavenging and apoptotic effects of Cordyceps sinensis fractionated by supercritical carbon dioxide. Food Chem Toxicol 43: 543-552, 2005.

23. Robertson JB, Williams JR and Little JB: Enhancement of radiation killing of cultured mammalian cells by cordycepin. Int J Radiat Biol Relat Stud Phys Chem Med 34: 417-429, 1978.

24. Wong YY, Moon A, Duffin R, et al: Cordycepin inhibits protein synthesis and cell adhesion through effects on signal transduction. J Biol Chem 285: 2610-2621, 2010.
25. Ni H,Zhou XH, Li HH and Huang WF: Column chromatographic extraction and preparation of cordycepin from Cordyceps militaris waster medium. J Chromatogr B Analyt Technol Biomed Life Sci 877: 2135-2141, 2009.

26. Hansen MB, Nielsen SE and Berg K: Re-examination and further development of a precise and rapid dye method for measuring cell growth/cell kill. J Immunol Methods 119: 203-210, 1989.

27. Telford WG, King LE and Fraker PJ: Evaluation of glucocorticoid-induced DNA fragmentation in mouse thymocytes by flow cytometry. Cell Prolif 24: 447-459, 1991.

28. Xing YN, Liang HW, Zhao L and Xu HM: The antitumor activity of exogenous and endogenous canstatin on colorectal cancer cells. Asian Pac J Cancer Prev 12: 2713-2716, 2011.

29. $\mathrm{Hu} \mathrm{J}$ and Verkman AS: Increased migration and metastatic potential of tumor cells expressing aquaporin water channels. FASEB J 20: 1892-1894, 2006.

30. Oikawa T, Sasaki T, Nakamura M, et al: The proteasome is involved in angiogenesis. Biochem Biophys Res Commun 246: 243-248, 1998

31. Liu Z, Tao X, Zhang C, Lu Y and Wei D: Protective effects of hyperoside (quercetin-3-o-galactoside) to PC12 cells against cytotoxicity induced by hydrogen peroxide and tert-butyl hydroperoxide. Biomed Pharmacother 59: 481-490, 2005.

32. Chang W, Lim S, Song H, Song BW, Kim HJ, Cha MJ, Sung JM, Kim TW and Hwang KC: Cordycepin inhibits vascular smooth muscle cell proliferation. Eur J Pharmacol 597: 64-69, 2008.

33. Chen LS, Du-Cuny L, Vethantham V, et al: Chain termination and inhibition of mammalian poly(A) polymerase by modified ATP analogues. Biochem Pharmacol 79: 669-677, 2010.

34. Nakamura K, Konoha K, Yoshikawa N, Yamaguchi Y, Kagota S, Shinozuka K and Kunitomo M: Effect of cordycepin (3'-deoxyadenosine) on hematogenic lung metastatic model mice. In Vivo 19: 137-141, 2005.

35. Wu WC, Hsiao JR, Lian YY, Lin CY and Huang BM: The apoptotic effect of cordycepin on human OEC-M1 oral cancer cell line. Cancer Chemother Pharmacol 60: 103-111, 2007.

36. Thomadaki H, Scorilas A, Tsiapalis CM and Havredaki M: The role of cordycepin in cancer treatment via induction or inhibition of apoptosis: implication of polyadenylation in a cell type specific manner. Cancer Chemother Pharmacol 61: 251-265, 2008

37. Lee CW, Wong LL, Tse EY, et al: AMPK promotes p53 acetylation via phosphorylation and inactivation of SIRT1 in liver cancer cells. Cancer Res 72: 4394-4404, 2012.

38. Guo P, Kai Q, Gao J, et al: Cordycepin prevents hyperlipidemia in hamsters fed a high-fat diet via activation of AMP-activated protein kinase. J Pharmacol Sci 113: 395-403, 2010.

39. Wu JY, Zhang QX and Leung PH: Inhibitory effects of ethyl acetate extract of Cordyceps sinensis mycelium on various cancer cells in culture and B16 melanoma in C57BL/6 mice. Phytomedicine 14: 43-49, 2007.

40. Zetter BR: Angiogenesis and tumor metastasis. Annu Rev Med 49: 407-424, 1998

41. Carmeliet P and Jain RK: Angiogenesis in cancer and other diseases. Nature 407: 249-257, 2000

42. Lu ZJ, Ren YQ, Wang GP, et al: Biological behaviors and proteomics analysis of hybrid cell line EAhy926 and its parent cell line A549. J Exp Clin Cancer Res 28: 16, 2009.

43. Nelson NJ: Angiogenesis research is on fast forward. J Natl Cancer Inst 91: 820-822, 1999.

44. Edgell CJ, Haizlip JE, Bagnell CR, et al: Endothelium specific Weibel-Palade bodies in a continuous human cell line, EA.hy926. In Vitro Cell Dev Biol 26: 1167-1172, 1990.

45. Edgell CJ, McDonald CC and Graham JB: Permanent cell line expressing human factor VIII-related antigen established by hybridization. Proc Natl Acad Sci USA 80: 3734-3737, 1983.

46. Adamson RH, Zaharevitz DW and Johns DG: Enhancement of the biological activity of adenosine analogs by the adenosine deaminase inhibitor 2'-deoxycoformycin. Pharmacology 15 : 84-89, 1977

47. Farthing D, Sica D, Gehr T, et al: An HPLC method for determination of inosine and hypoxanthine in human plasma from healthy volunteers and patients presenting with potential acute cardiac ischemia. J Chromatogr B Analyt Technol Biomed Life Sci 854: 158-164, 2007. 